\title{
The Moral Dilemma in Information Dissemination in a Democratic State of Digital Media
}

\author{
Laleye Solomon Akinyemi \\ Department of Philosophy, Adekunle Ajasin University, Akungba, Akoko, Nigeria
}

Email address:

laleyesolomon@gmail.com

\section{To cite this article:}

Laleye Solomon Akinyemi. The Moral Dilemma in Information Dissemination in a Democratic State of Digital Media. International Journal of Philosophy. Vol. 9, No. 2, 2021, pp. 106-110. doi: 10.11648/j.ijp.20210902.15

Received: May 2, 2021; Accepted: May 24, 2021; Published: June 7, 2021

\begin{abstract}
Journalism is a profession charge with the responsibility of information dissemination. It also functions as the link between the government and the governed particularly in a democracy. The performance of these functions has been greatly enhanced across the globe by the advancement in information and communication particularly that of digitalization, convergence of computers, and telephony technologies. Unfortunately, these narrowed the wide gap that hitherto existed between citizen journalism and conventional journalism and consequently raised the bar of the moral responsibility that the profession owed the general public in a democracy. The practice of journalism generate problems such as; access to information, truth, censorship, corporate, national and public interests. All these undermined the ethics of responsibility on the part of the government and journalism profession. The article, therefore, attempts a critical look at journalistic practice with emphasis on the use of internet to produce, disseminate and receive information in a digital media environment like Nigeria. It argued that the transition from analogue to digital would better enhance access and dissemination of quality and comprehensive information if the ethics of responsibility is subscribed to by the journalists and the political leaders. The article is philosophical and it adopts the philosophical methods of critical analysis and prescriptivism.
\end{abstract}

Keywords: Digital Media, Ethics of Responsibility, Citizen and Conventional Journalism

\section{Introduction}

The emergence of internet and advancement in information and communication technologies combined to broaden the nature and scope of journalism, as well as the ethics of the profession in contemporary age. Journalism has advanced beyond the traditional print, radio and television to include, digital, online, and cyber journalism. Aside from making the task of journalism less hazardous and cost effective, the internet has also "created a new sphere where everyone can be journalist all you need is a computer and an opinion- no training necessary." [1] Consequently, both objective and subjective, real and imaginary experiences could be shared even by untrained citizens. This has expanded the scope of who could practice journalism, it has also made the profession vulnerable ethically. In other words, professional journalists struggle with tweeters, bloggers, and other social media users in the media space in order to inform, entertain and to educate the general public.

It is remarkable that digital media has "reshapes and redefines the ethical issues confronting journalists when operating online or making use of online facilities" [2]. The source of information and the authenticity may not quickly be ascertainable since citizen journalists who are not trained can also access the websites to upload or download information. More importantly, is the fact that journalistic practice has moved beyond the traditional methods of news gathering and dissemination, so are the corresponding challenges and ethical issues involve. The new ways of packaging and disseminating information now required among other things; access to internet facilities which could at times be problematic due to poor or unavailable network connection or other related problems However, journalists explore the opportunities provided by cafe, media resource centres and libraries to carry out their duties and to learn new skills on online journalism, such skills include addition of contents to the web, creation of hypertext links, learning photographic skills on how to take digital photograph and upload to computer, site or blogs. These opportunities provided by Digit media was noticed by Hayes, Singer and 
Ceppos who all opined that; "old assumptions about journalistic roles and values can no longer be accepted uncritically nor old approaches to them continued indefinitely" [3].

The practice of journalism in contemporary society has however, transcended the circle of the professional journalists to include every Tom, Dick and Harry. Citizen Journalism has made it a reality for everybody to be media creator, owner and actor instead of passive user. [4]. Consequently, one can submit in the words of Hassan, S. that, "the digitalization of the news production and the diffusion capabilities of the internet challenge the traditional journalistic professional culture." [5].

Both professional and self-proclaimed journalists used their vantage positions of access to internet and the scope of the coverage of the internet facilities to disseminate and enlighten the public on government policies. They also influence the thinking of the public on national policies. These are made possible because information from the digital media are capable of influencing the mind-sets of the public. The unsuspecting public assumed rightly or otherwise that information are published by professionals guided by the code of conducts of journalism. This accounts for why, Ekeanyanwu and Edewor quoting Livus opined that, "the nature of media technology prevailing in a society at a particular point in time greatly influences how the members of that society think, act and behave" [6]. In other words, the public could easily be misinformed and misled.

In another dimension, inaccurate and non-objective report of event could be attributed to overzealousness of some journalists as well as regime attitude that is repressive and intolerant. The government especially in developing nations often initiate policies that censor press freedom in reporting event the exact way it is. This called to question the proclaimed freedom of expression as well as the right to know which are fundamental to participatory democracy. How can journalists effectively balance the right of the public to access information and, the right to be secretive with information adjudged to be of national security interest by repressive regime? To what extent does professional ethics affect the practice of online journalism? The attempts at answering these question would be made using Nigeria as a point of departure. The concern of this article therefore, is with the conduct of the professional journalists as it relates to truth, access to, and dispassionate dissemination of information in this digital age and how to checkmate the influx of unethical publications from the non-professional journalists in the media space. Finally, how the ethics of responsibility could be re-engineered among the stakeholders of news and information.

\section{The Emergence of Technology}

The Twenty-first century witnessed remarkable advancement in technological development which has impacted, among other things, on the social life of an average individual especially her access to information. Hitherto, Nigeria communicated with one another through various traditional forms, many of which persists in attenuated forms in the $21^{\text {st }}$ century. These traditional forms include mobile theatres, festivals, the rumour mill, moonlight folk tales, folk music, the talking drum, semiotics or coded language among others. [7].

The Awake Magazine, eulogizes the African Talking Drum in the following terms:

... talking drums are used as telephones and telegraphs. All kinds of messages are sent - to announce births, deaths, marriages, sporting events, dance, initiation ceremonies, government messages and war.

Sometimes, the drums carry gossips or jokes... from one village to another, a distance of over 100 miles (160 kilometers), a message could be sent in less than two hours or much less. Communities in the Congo have not yet adopted electric signals but possess however, a system of communication quite as affective. Their huge drums struck in different parts convey language as clear to the initiated as vocal speech [Emphasis added]. [8]

The communication/information potentials of the talking drum are mostly useful to only the initiated.

The emergence of technology in Nigeria media space aids production possibility boundaries of media practitioners. Within the last two decades many information dissemination outfits in the country took advantage of the advancement in technology by going online. These outfits include Nigerian Tribune, Vanguard, Sun and Punch Newspapers to mention these few. Today, Nigeria has well over 5000 blogs and 50 online newspapers with most of them also circulating regular newspapers too. [9]

The digitalization of information processes enhances information gathering, sorting, structuring and publishing with minimal cost and stress. For instance, the stress-filled method of typesetting on the old manual type-writer has given way to less stressful and cost-effective Desktop publishing, where computer and software are used to combine text and graphics that could be printed on typesetting machine with relative ease. Other information processes such as editing, page lay-out, pictorial representations, formatting, proofreading etc can now be easily done with the use of computers. Today, a newspaper publishing house in Abuja or Lagos in Nigeria can conveniently send electronic copy of any particular edition of her production to another town to be printed and circulated. Some newspaper firms, with the aid of the internet are able to go into news production more than once in a day, thereby "breaking news" as they occur.

Although, this has raised the standard of information, entertainment and education available to the public, it has also increase competition in the industry, It is obvious that, "editors, pressurized by intense competition for readers, demands that staff cut ethical corners; and competitions among staff encourages some to respond. Lecturing the journalists about ethics is as pointless as advocating celibacy to sailors arriving in port after six months at sea." [10] Consequently, there is tension between the centrifugal and centripetal forces of the reflectiveness of a moralist and the reality of the tough world 
of the tabloid newspapers. News production either in print or online is therefore characterized by defamation of character, sensationalism, deliberate distraction of the public from burning issues, economy of the truth of events or deliberate refusal to report known occurrences, gagging of the press by repressive regimes, propaganda, endorsement of preferred political candidate, expression of partisan opinions and promotion of political views etc, which are all at variance with the ethical standard of professional journalists that include selflessness, fairness, balanced and accurate presentation of facts without prejudice to the fact that.

"Every journalist-reporter as well as editorial writersubjectivizes his journalism. He cannot be objective even if he would like to be. Every article, every sentence, every newscast, every movement before the camera, every voice inflection on radio is subjective." [11]. In spite of the reality that perfect objectivity in news reportage is impossible as pointed out by Adeyeye, it is on record that, all professional journalists learn the fundamental values to represent truthfully what the public should know about public affairs that affect their well- being so that they could consciously form an opinion about those affairs.

Suffice it to say that, the propensity at which news circulate is better imagined in a digital environment. Damaging stories concerning individuals or government are capable of having ripple effects and, the retractions of such news items may not carry the same weight as the initial one. These have increased tremendously the number of cases in the court of law over libel or slander. There is thus the need for the interrogation of journalists' activities with the ideal philosophical method of critical reporting in a democracy such as Nigeria where freedom of information and expression should have a pride of place.

The fundamental questions that this article addresses therefore are; should journalist always publish true information of any event as a principle of social responsibility? Should national or security interest undermine the publication of any true story? What constitutes public interest? What constitutes publishable and unpublishable truth? Is morality ambivalent and, consequently a subjective concept in a democracy? Should politics be devoid of morality? If truth telling is morally required, is propaganda morally permitted?

Answers to these questions are within the confines of morality in professional journalism and government business.

\section{Morality, Journalism and Constitutionalism in Contemporary Nigeria}

Every society believed in the necessity of a line of demarcation between right, good, just, fair and wrong, bad, unjust and unfair conducts so as to foster peaceful coexistence. When this is being done, we are in the realm of morality. This perhaps must have informed the definition of Long and Sedley that, "morality is the disjunction between right and wrong, between what a human is and what he ought to be." [12].

Morality is essentially human-centred. It is more concerned with the relationship that ought to exist between individuals as separate entities on the one hand and, as groups within the society on the other. Oftentimes, how the human person relates with the environment around it and how the leaders relate with the led could be a subject of moral concern. The discourse on morality therefore, is meaningful when situated within the context of the individual as well as the communities where the different individuals and groups live.

Within the context of the individual, morality manifests in the form of self-interest while, in the context of community that hosts the individuals, it manifests as corporate or societal interest. In other words, there is always a tension between egoism [13] and altruism [14] in any human society, but it is cognitively appropriate to say that the survival of any human society is a function of the level of altruistic disposition of the different individuals in that society because, the egocentric tendencies of the individual person would undoubtedly gravitate human society towards the detested Hobbesian state of nature characterized by lawlessness, anarchism and where selfish interest of the individuals reign supreme. [15] Part of the ethics of journalism irrespective of whether it is analogue or digital include the promotion of public interest.

In a democracy, the society would want to believe that the journalists would not betray public interest by being dishonest more so, when there are consciously designed mechanisms in the form of code of conducts that provide oversight on journalist practices. Suffice it to say that trust rest on integrity, whims and caprices of the individual journalist.

There is an inseparable link between morality and politics but the defining feature of African political life seems to be a version of the prescriptions of Niccollo Machiavelli in The Prince. [16] The upshot of Machiavelli's position in this book, is that the leader is not bound by the norms of traditional morality in the discharge of his duties. What should matter in politics is the maintenance of the ruler's whims and caprices. This has inspired autocratic and repressive regimes across Africa. C. O. Agunlana rightly observed with particular reference to the African continent that; "many African leaders seem to have accepted the principle that expediency should always be placed ahead of morality, and that leaders should practice duplicity in statecraft or in their dealings with the people. In other words, African leaders seem to have accepted the Machiavelli's dictum that a leader should be wily, ruthless and brutal in the way he deals with his subjects or those he governs." [17]. In the context of access to, and dissemination of information, Nigeria government would not want the publication of any information that could indict the government or any of its representatives no matter how true such information is.

Conflicting information often emanates from political leaders and media on matter of national importance, this impinge on truth as an important ingredient of morality. For 
instance, during the first wave of Corona Virus, it was widely reported with pictorial evidence in national dailies, the arrival of some "Chinese Doctors" into the country to help the government in her fight against the spread of the virus. To date, no evidence of any location or victim treated by the Chinese medical team after staying almost six weeks in the country before their departure. In the same vein, there has been two sides to every claim to the number of casualties recorded on daily basis in the fight against insurgencies in Nigeria. The figures given and substantiated by the media is usually different from those of government spokesperson, so is the claim of the level of decimation of the insurgents. The Freedom of Information Bill (FOI) and the Media Practitioners Enhancement Bill are efforts by media professionals to free the information sector from the tyranny of political arbitrariness and deceit. But, the bills have achieved next to nothing in ensuring the freedom of the press. The justification that can be advanced for the contrary information often disseminated to the citizens by government officials and the Press is that of moral contextualism. By moral contextualism, reference is to the position that judgement involving expression such as good, acceptable and required have context-sensitive truth conditions. In elementary logic however, two statements are regarded as contraries, if they cannot both be true but they could both be false.[18] Therefore, to leave the public in the dark as regard true situation of event breeds rumour, distrust as well as heightened the search for alternative source of information.

The importance of information in a democracy cannot be overemphasized. It is on the basis of information that the electorates are guided in decision making particularly, on who to vote for, programme or manifesto to align with, engage in robust public debate, scrutinize public officials, and an avenue to combat corruption.

The Media is central to information dissemination in a democracy. The press, both print and electronic versions wield an undisputable influence by virtue of her responsibility to inform and enlighten the populace on the policy thrust of a democratic government. This role is expected to be discharged devoid of sentiment. Democracy, following the thought of Aristotle "is a political arrangement in which political power is vested in the majority of citizens." [19] This, by extension involves free election, free assembly, transparency, accountability, government by the people and social equality. In the bid to actualizing the visions of democracy, the constitution of the Federal Republic of Nigeria recognizes the rights of inclusiveness in running the affairs of nation. For instance, journalism derives its power as the fourth estate of the realm from the 1999 constitution. Section 22 of Chapter 2 states that;" the press, radio, television and other agencies of the mass media shall at all times be free to uphold the fundamental objectives contained in this chapter and uphold the responsibility and accountability of the government to the people." [20] These aspects of the constitution emboldened and strengthened journalism in Nigeria to a reasonable extent. However, the dispositions of government have not facilitate the entrenchment of participatory democracy through free, fair and credible elections. Digital media is capable of facilitating the transmission and announcement of electoral results from the polling units to the central collation centres but for reasons best known to the present administration in Nigeria, it is reluctant to sign into law the electoral reform act which interalia emphasizes digital process for elections.

Journalism has the obligation to hold the government accountable to the people in the discharge of government's political, economic, social, and educational policies, these in addition to another constitutional proviso that; "every person shall be entitled to freedom of expression, including freedom to hold opinions and to receive and impart ideas without interference"[21] It will therefore be tantamount to disinformation and a negation of the essence of democratization when the general public could not access information on government activities.

The practice of Journalism in Nigeria in this digital age prioritizes personal and corporate interests over public interest. It is a common occurrence for people to pay the journalists for news to be included on the media agenda. Most journalists received gifts either in cash or in kind, freebies and "brown envelopes" so as to help publish or distort news items. This compromises the ethics of responsibility the profession owed the public.

It is true that journalists learn the fundamental values to represent truthfully what the public should know about public affairs, especially those that affect the well- being of the public so that the public could form opinion about those affairs. But prevailing economic, social and political conditions of palpable fear, unemployment, bad pay, and harsh editors, often dull the commitment to these values in journalists. Cases of attacks on the press, death threats to journalists, arm twisting of the editors who publishes story critical of the government, and censorship are part of the challenges that confronts journalists. These, according to Ben Tomoloju vindicates the wariness of the media stakeholders and their commitments to the full democratization of the polity in order to create a conducive environment for the practice of journalism [22] The fact that human wellbeing in terms of self-interest and community interest are the pivots upon which morality oscillates, the political leaders, through good governance in a democracy are, therefore, expected to moderate the interests of both the individuals and the community and, decide what is right and wrong. In doing this, the private interests of the political leaders ought not to override the community' interest. This suggests that the political leaders ought to be more of the custodians of morals in any political community, their actions and inactions in public life ought to provide justifications as well as the impetus for public morality. To this end, the extent at which these roles have been played especially in information dissemination in a supposedly democracy like Nigeria leave much to be desired. Propaganda is used to promote public loyalty or private interest of political leaders.

There is thus the need for the inculcation and demonstration of the ethics of responsibility by all the 
stakeholders in the society, particular the media practitioners, the government and its representatives. By ethics of responsibility, reference is to the morally based obligations owed the governed by the individuals, professional bodies or the state. It could by converse be the moral duties that the governed owed the state in return. In this wise, it is cognitively appropriate to say that the professional journalists has a responsibility to access information and to rightly inform the public on policies that could have effects on the well- being of the society. However, the freedom of the journalists must go parri-passu with legal, social and selfresponsibility to forestall anarchy.

The journalist must respect the responsibilities it has towards the public, these include truth-telling. It is the responsibility of the journalist to publish all the facts of a case devoid of falsification so as to suit primordial interest or self - interest.

In the same vein, citizen journalists has the moral obligations to refrain from intrusion into a legally constituted profession in which they are not members. Government should be more transparent and facilitate unhindered access of professional journalists to information that has implications on the well-being of the society.

\section{Conclusion}

The paper noted that digital media has transformed the contents, structure and modalities of information dissemination in Nigeria. It has also enhanced new skills acquisition among media practitioners but these positive impacts have not totally erased the challenges associated with journalism in developing nations like Nigeria. Citizen journalism now wax stronger because of unrestricted access to the internet as well as to information thereby constituting a threat to the ethics of journalism. In the same vein, conventional journalists most often jettisoned their ethics of responsibility to the public through the falsification or deliberate distortion of the facts of event. Also important is the vital role of government to allow unrestricted access to information so as to enhance transparency and accountability which is the hall mark of democracy. Finally, the paper argued for the respect of the ethics of responsibility by all stakeholders in the media.

\section{References}

[1] Burkholder, C. cf Ayodeji Awobamise Olalekan. (2014). Digital News Media, Ethics and Freedom of Expression - A Nigerian Perspective Mediterranean Journal of Social Sciences $\quad$ Retrieved 18-4-2021 https//www.researchgate.net/publications/271104467.

[2] Deuze, M and Yeshua, D. (2001) Online Journalists Face New Ethical Dilemma: Lessons from the Netherland. Journal of Mass Media Ethics 16 (4) 276.

[3] Hayes, A. S., Singer, J. B., and Ceppos, J. (2007) Shifting Roles, Enduring Values: The Credible Journalist in a Digital Age". Journal of Mass Media Ethics 22 (4) 275.
[4] Ezeibe, C. C. \& Nwagwu, E. J. (2009) Media Imperialism and Crisis of Development" International Journal of Communication 10. 65-66.

[5] Hasan, S (2014) Mass Communication, Principles and Concept New Delhi: CBS Publishers. 770

[6] Ekeanyanwu, N. T. \& Edewor, A. P. (2009) Cultural Implications of ICTs and Globalization of the Nigerian Society Journal of Communication Media Research Vol 1 (2). 17.

[7] Iyare, Tony (2004) The Role of the Press in Promoting Responsible Leadership Governance: Nigeria and the World Sylvester Odion-Akhaine (ed) Ikeja: Centre for Constitutionalism and Demilitarisation, 209.

[8] Amadi, Fred (2007) Public Information and African Traditional Communication Delivery System. Sophia: An African Journal of Philosophy 9 (1) 62. doi: 10.431/Sophia.v9il.38759.

[9] Ayodeji Awobamise Olalekan. (2014.) Digital News Media, Ethics and Freedom of Expression- a Nigerian Perspective Mediterranean Journal of Social Sciences Retrieved 18-4$2021 \mathrm{https} / / \mathrm{www}$. researchgate.net/publications/271104467

[10] Randall, David (2001). The Universal Journalists. London: Pluto Press. 13.

[11] Merill Cf Adeyeye Samson Dare (2004) In Defence of Subjective Reporting: A Linguistic Perspective Ibadan Journal of Humanistic Studies, no 13\&14. 106.

[12] Long, A. A. and Sedley. D. N. (1987) The Hellenistic Philosophers: Translation of the Principal Sources with Philosophical Commentaries. Cambridge: Cambridge University Press, 367.

[13] Egoism is an ethical concept that emphasizes selfinterestedness.

[14] Altruism is a moral concept that prides selflessness as a moral action.

[15] Ebeh, John Igbogo (2020). Political Participation in John Locke: An Assessment Falsafa: Journal of Philosophy 3 (1) 138.

[16] Machiavelli, Niccollo. (2015) The Prince. A New Translation by Bondamella, P. Oxford Oxford University Press.

[17] Agunlana, C. O. (2014) Moral and Political Education as Foundation for a Reasonable Social Order in Africa. Ethics and Public Affairs. F. A. Adeigbo, Dipo Irele, Amaechi Udefi (eds.) Ibadan: Ibadan University Press, 11.

[18] Otakpor, Nkeonye (2000) A preface to Logic. Benin City: Omone Books, 68.

[19] Labinjoh J. (1994) Sociology of Power Relations. Otite, O. (ed). Sociology Theory and Applied. Malthouse Press, Lagos.

[20] Constitution of the Federal Republic of Nigeria (Promulgation) Decree (1999). Section 22 Chapter 2.

[21] Constitution of the Federal Republic of Nigeria (Promulgation) Decree (1999) Section 39 (1).

[22] Ben Tomoloju (2004) Media Culture and the Democratic Process Governance: Nigeria and the World Sylvester OdionAkhaine (ed) (Ikeja: Centre for Constitutionalism and Demilitarisation). 199. 